\title{
3D VISUALIZATION AND PHOTO-REALISTIC RECONSTRUCTION OF THE GREAT TEMPLE OF BEL
}

\author{
Ahmet Denker \\ Faculty of Engineering and Natural Sciences, Istanbul Bilgi University, Eyup 34060, Istanbul, Turkey. \\ ahmet.denker@bilgi.edu.tr
}

\section{Commission II}

KEY WORDS: Palmyra, Temple of Bel, 3D Visualization, Reconstruction, Cultural Heritage

\begin{abstract}
:
The Great Temple of Bel in Palmyra was a unique edifice which had blended the well established lines of Greco-Roman architecture with the art and taste of the Orient. With the gilded bronze capitals of its 41 Corinthian columns it was the product of enormous effort and budget. It was the gem of a remarkable epoch of wealthy Palmyra and mighty Roma. With its splendidly decorated adyta ceilings it became a source of inspiration and imagination for Western architecture and decorative arts. While continuing to captivate the World, it was leveled and vanished as a grim result of conflict based vandalism. The aim of this work is to piece together this, the most eloquent and stupendous monument of the Roman East, from its ruins and reconstruct it as it was once extant. Its loss is irreplacable, but its photo-realistic reconstruction can offer some solace by waking the memories of the great temple as in the past. The lost reality of the Great Temple of Bel is revived here by digitally constructing its "ghost images."
\end{abstract}

\section{INTRODUCTION}

The Great Temple of Bel, one of the latest victims of terrorist vandalism, was among of the most impressive edifices which were ever brought to light by archaeologists. In 2015, on the last day of August, the civilised world was shocked with the news of the destruction of it, by ISIS. Before blown up by jihadists, Temple of Bel was the most impressive and renowned building in Syria. It was the vestige with which Palmyra was associated.

The Great Temple of Bel was a remarkable example of the monumental architecture which blended the Greco-Roman architecture with Oriental art. The hybrid elements of this temple demonstrated the numerous cultures that frequently overlapped and intermixed in Palmyra.

The defining feature of the devastation of this temple was the intentional targeting of the material evidence of Palmyra's multi-cultural identity.

After Palmyra was rescued, it was obvious that the temple was lost forever. Satellite pictures showed that the entire structure collapsed in a heap of rubble. The only part which remained from the temple was the western doorway into the sanctuary building. With its destruction and disappearance, another irreplaceable treasure of the world cultural heritage was lost to posterity.

Temple of Bel was not only historically and culturally significant, but it was also beautiful. Hundreds of thousands of tourists who were visiting Palmyra every year used to be captivated by what they saw: The ruins of temple were remarkably well preserved and rose in splendour in the surrounding Syrian Desert. Regrettably, since the end of 2015 summer, that view of the Temple of Bel that tourists used to savour no longer exists. The temple had crumbled into obscurity in the surrounding desert.
The objective of the work presented here is to revive in our memory this most imposing monument of the pillaged ancient city of Palmyra.The Great Temple of Bel is restored virtually to the condition it formerly was in the Roman times. By using information from ancient texts, lithographs and architectural drawings, virtual models of the temple are created showing how it used to look.

This reconstruction endeavour's target is to provide some healing for the lost temple in memories. Its virtual rediscovery and visual recovery can never replace or totally remedy the loss of the temple, but it can visually wake the memories and provide some experience of the temple as in the past.

\section{BEL: FIRST VIEW OF THE TEMPLE AND THE TRIAD OF DEITIES}

Temple of Bel used to stand as a gigantic, quadrangular architectural complex in the south-eastern part of Palmyra. It was enclosed by the ancient city walls and surrounded by the grove of palm trees. This temple was consecrated to Bel, the most important god of Palmyra. It rose at the eastern-end of a long colonnade. At first sight, the architecture seemed familiar to the beholder, since it resembled all the other sanctuaries in the Greco-Roman world.Through its Corinthian style columns it displayed a silhouette which corresponded to the fashion of the AD II ${ }^{\text {nd }}$ century.

But, at the second glance, the building seemed to be different, if not strange: the entrance door to the sanctuary was standing, not at the front, as one would have expected, but surprisingly at one of the two sides. In addition, cella had windows; a temple with windows had never been seen in the Greco-Roman architectural canon. Instead of a gabled roof, as one saw in every other temple, the building had a terrace with parapets at the top. The 
most striking feature, however, was that in the Great Temple there were columns bearing capitals of gilded bronze.

When and for what divinity or deities the temple building was built, these questions will be convenient to answer before the detailed reconstruction of the temple itself is discussed.

This temple was the habitation of Bel, the most holy of the deities of Palmyra. Bel became the omnipotent God, the creator of the astronomical heaven, like the Greek Zeus, the king of the gods, whose symbol was the planet Jupiter. Bel is not a sun god but a cosmic god. He was not the only God who was worshiped in his temple; Two other gods were with him as subordinates: Yarhibol, whose name probably means "moon of Bel", and Aglibol means the "calf of Bel ", representation of the deity as cattle, bull or calf was frequent in the Orient. The three divinities formed a triad; The adjoining gods are portrayed as standing to the right and the left of Bel. Around Aglibol's head, is the moon squall, and Yarhibol bears the sun-disc.

Puchstein had assumed that the Bel-sanctuary was the oldest building in Palmyra, he said: "Remains of older periods of culture are nowhere to be observed." When he visited Palmyra (in 1902) the cella of Bel was indeed the oldest building visible above the ground. But the archaeological research of the following years showed that this conjecture was partially correct, as the remains of older and, indeed, purely Hellenistic buildings were detected as buried under the sands of desert.

Thanks to a dedicatory inscription found during excavation of the temple, we had learned that the cella building was erected in the Augustan period (27 BC-AD 14), and the sanctuary was consecrated in $\mathrm{AD} 32$, but the complex was not completed until early AD II ${ }^{\text {nd }}$ century.

The architect is not known, but from the use of local limestone the conclusion was clear for many: The master of the Temple of Bel must have been local, maybe from Syrian Antioch. Having traced the Greek influences back to Hellenistic architect Hermogenes of Priene and the Temple of Artemis in Magnesia on the Meander, it has also been suggested that the architect could have been Greek, but with a Syrian origin (Seyrig, et al. 1975). This great master of the Temple of Bel had, on one hand, followed the tradition, and on the other hand, prepared the way for the unifying architecture of Greece, Rome and the Orient by opening the hinterland to influences from the West.

\section{THE GREAT TEMPLE OF BEL: DESCRIPTION AND RECONSTRUCTION}

The temple of Bel was the most magnificent monument of Palmyra; conceived as such at the very epoch when the city took its rise, it remained so until it was gravely mutilated in 273 by Roman soldiers during the war waged between Queen Zenobia of Palmyra and Emperor Aurelian of Rome.

We learn from Historia Augusta, the Life of Aurelian (Part 2,31, 7-10) Aurelian himself was concerned about the pillage of the Temple of Bel that he called the Temple of Sun and presented the plan for its restoration in his letter: "Now as to the Temple of the Sun at Palmyra, which has been pillaged by the eaglebearers of the Third Legion, along with the standard-bearers, the dragon-bearer, and the buglers and trumpeters, I wish it restored to the condition in which it formerly was. You have three hundred pounds of gold from Zenobia's coffers, you have eighteen hundred pounds of silver from the property of the
Palmyrenes, and you have the royal jewels. Use all these to embellish the temple; thus both to me and to the immortal gods you will do a most pleasing service. I will write to the senate and request it to send one of the pontiffs to dedicate the temple."

The misfortunes of the Temple did not end there, it had been restored and destructed more than once, and finally blown into pieces.

Temple of Bel had remained partly visible and partly buried under sands of Syrian desert like the rest of Palmyra, waiting to be rediscovered. Dawkins and Wood, as early as 1753 , were the first to resuscitate the monument before the eyes of an audience devoted to orientalism and antiquities. After Wood (Wood, 1753) published The Ruins of Palmyra, otherwise Tedmor, in the Desart interest for the antiquities of Palmyra was at its acme. Wood had stimulated a special interest for the Great Temple as he mentioned it as the major temple of quotes and identified it, as expected, with Templum Solis which is mentioned in the Life of Aurelian (Historia Augusta Aurelianus) With Giovanni Battista Borra's drawings, Wood's book had been the main repository of information as regards to graphical data. These drawings, a little devoid of fancy, but relatively exact, were succeeded by others, more extravagant, due to the pencil and brush of Louis Francois Cassas (1799); we may add to them a plate of Count Leon of Laborde of 1837. Photos taken between 1867 and 1876 by Felix Bonfils which provide the most complete visual record of Palmyra from the 19th century have been another indispensible information source which enabled the realisation of this project.

It was when the first truly scientific surveys were carried out by two German expeditions, one directed in 1902 by O. Puchstein, the other in 1917 by Theodor Wiegand; the architectural drawings of the temple were rendered by architect B. Schulz (Schulz, 1932).

The 1972 publication of Seyrig, Amy and Will displayed the well-illustrated and not yet outdated research of the temple, it compiled and presented almost everything we need to know for the restitution of the Temple of Bel, which would enable the monument to be revived and justify the present reconstruction work (Seyrig et al, 1975). Finally, A small watercolour by Jane Elisabeth Digby which in the summer of 1972 Henri Seyrig managed to find and included in the book by the authors (after Seyrig's unexpected death) showed the building in its unruined state.

With inspiration derived from these sources, and encouragement from the advances of computer graphics technology, modelling and reconstruction of the ruins of Palmyra had been the subject of a recent book : Reviving Palmyra in Multiple Dimensions: Images, Ruins and Cultural Memory. This book which was co-authored by the author together with M. Silver and G. Fanni provides a virtual reconstruction of Palmyra with the aim of lifting it from its ruins (Minna et al, 2017). In a preceding work the author had presented the earlier model of the temple together with the other landmarks of Palmyra (Denker, 2016 ). In sequel, this work is dedicated to the Great Temple of Bel and aims at reviving it with a more detailed and comprehensive reconstruction.

The great sanctuary dominated Palmyra which stretched at its feet, with its monuments, colonnaded streets and with its 
houses, olive trees and vineyards far to the north-west.

The following is to be noted concerning the imposing position of the temple, when one stood at the center of the city where the crossroads of Cardo (central section of the colonnaded street) and Decumanus (eastern section of the colonnaded street) was marked by a large tetrapylon (Fig. 1), and walked along the latter towards south-east, he reached, Triumphal Arch.

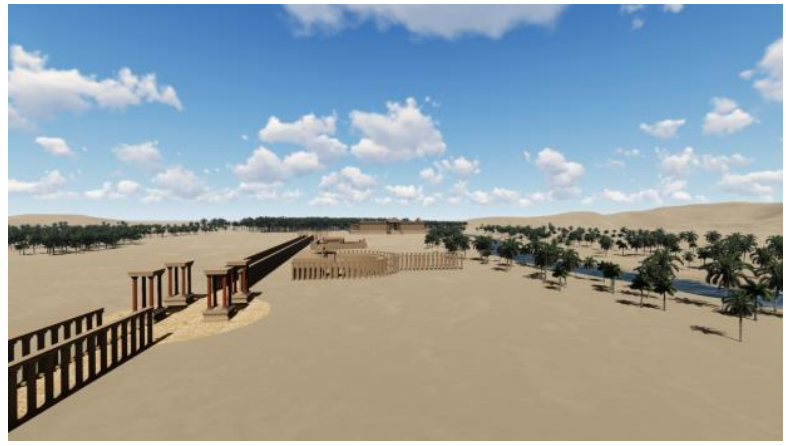

Figure 1 . Center of the city was marked by a large tetrapylon

After Triumphal Arch, colonnaded street made a turn of 30 degrees southwards (this part was never finished) with respect to this main road, and there was the Great Temple. (Fig 2)

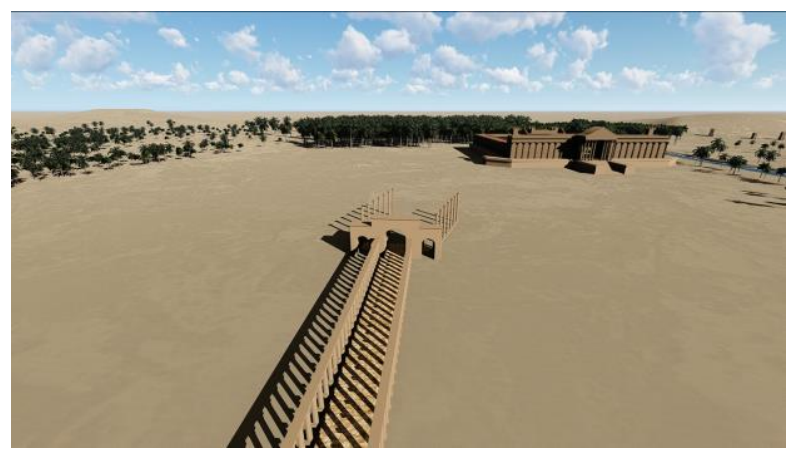

Figure 2. Triumphal arch directs the view to the entrance of the temple

In response to the question why bend had been arranged in this particular direction, and why the Triumphal Arch had just been erected at this point, it is hardly likely to be mistaken in responding that so the bend after the Triumphal Arch would direct the view precisely to the propylaeum of the temple (Fig. 3).

The complex was crowned by the groom of palm trees behind it, and a pleasant stream was skimming it. The existence of this stream was mentioned in Pliny as: "Situated in a vast expanse of sand and renowned for its fertile soil and pleasant streams, the ancient city of Palmyra was a stopping point for caravans traversing the Syrian Desert" (Pliny the Elder, Natural History 5.88.1). Through satellite imaging and remote sensing the existence of this river was also confirmed. The complex was built of sand stone, its appearance and colour was described by Gertrude Bell in a letter as : "...looks like marble and weathers a golden yellow ..." Golden yellow of the building together with dark green the palm grove and light blue of the nearby stream had formed a spectacular composition.

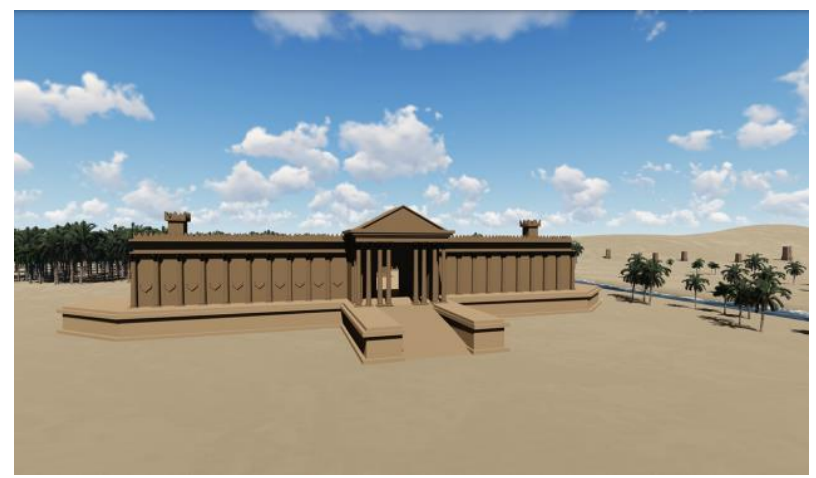

Figure 3. Triumphal arch directed the view to the entrance of the temple

Palmyreans reached the courtyard, on the western side, by the propylaeum which was preceded by a monumental staircase. Propylaeum was occupying about a sixth of the length of the western peribolos wall, it had an open-plan portico colonnaded with 8 Corinthian style columns (Fig.3). Both the propylaeum and the staircase had vanished a long time ago.

The temple of Bel stood in the center of a large temenos lined with porticos. The west-side was the entrance side and it was marked by a high one aisled stoa along the whole length. Against it was running a much lower but two-aisled stoa along three other sides of the court (Fig. 4).

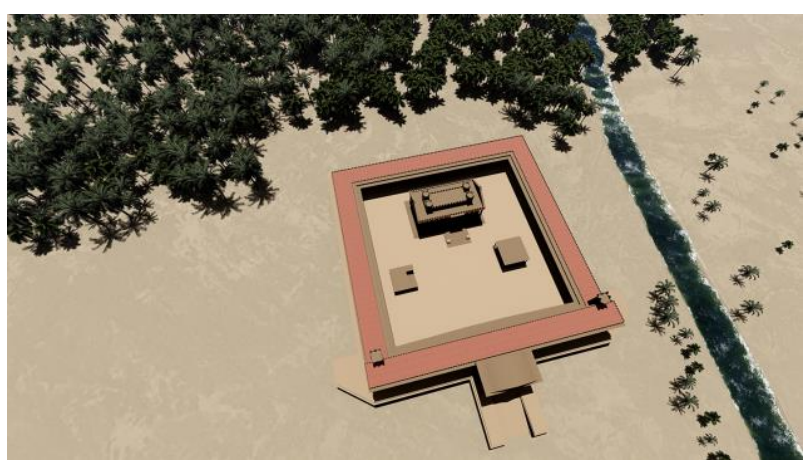

Figure 4. The temple of Bel stood in the center of a large temenos lined with porticos

The cella was on a podium in the middle of an almost square open court (175 by 180 meters). The portico which was surrounding the courtyard had a depth of 30 meters which meant that the outer dimensions of the temenos were extended to 205 by 210 meters. The cella stood in the court asymmetrically, facing the North. Its main axis was tilted only by 5 degrees from the North-South axis. The main axis of the cella divided the open court in two portions with a ratio of 3:2. Western and eastern portions were approximately $105 \mathrm{~m}$ and 70 $\mathrm{m}$ deep, respectively. The edifice was a pseudo-dipteral Corinthian style building. There were 41 columns, altogether: 8 columns at façades, 12 at the west flank and 13 at the east flank. Column height was $15.81 \mathrm{~m}$, and base diameter was $1.33 \mathrm{~m}$, the height of the building was $33.14 \mathrm{~m}$. Columns of peristyle were topped with bronze gilded capitals!

There is no doubt that this significant detail added to the edification of the temple, and to its cost greatly. Such capitals 
were seen rarely, and it should be kept in mind that the great temple of Baalbek, had never possessed more than stone capitals, like the vast majority of the ancient temples. Temple of Bel, on the contrary, possessed 41 bronze capitals that meant tons of bronze! (Fig. 5)

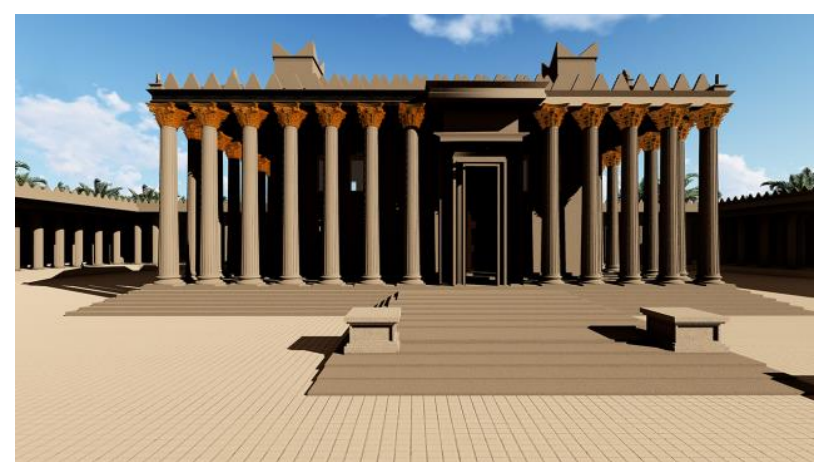

Figure 5.Columns of peristyle were topped with bronze gilded capitals that meant tons of bronze!

This detail alone suffices to say that constructing the Temple of Bel had been a herculean endeavour that needed enormous funds. It was the unique product of an epoch of prosperity in the Roman East.

In contrast with this lavish and extravagant choice in the capitals, the architraves were devoid of any kind of ornamentation, they were characterized with one window in the middle which were flanked by two medallions (Fig.6).

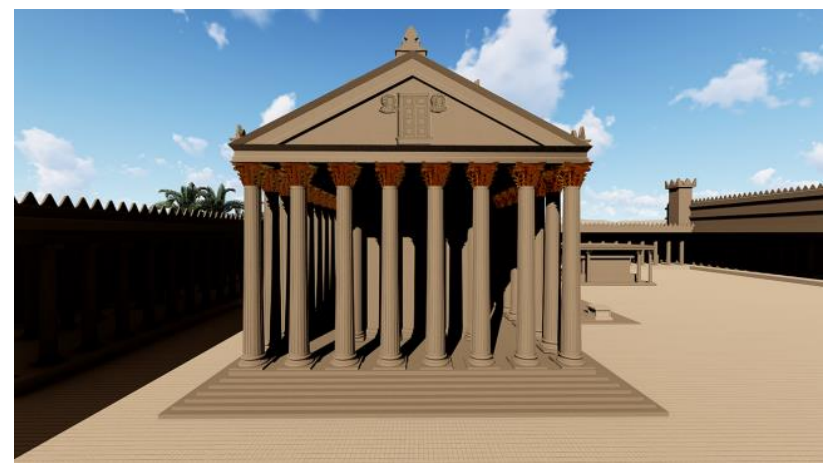

Figure 6. North façade

One discerns that this arrangement could be one of the trails of the supposed influence of the Hellenistic architect Hermogenes upon the architect of the temple of Bel. Hermogenes also had implemented a similar arrangement in the architrave of the Temple Artemis in Magnesia on the Meander. In the Temple Artemis in Magnesia on the Meander the main, the architrave (which is still extant) had a primary window or opening in the middle, it was flanked by two smaller windows on both sides. The main window was kept in the Temple of Bel whereas the smaller windows were replaced by two medallions.

A different impression was felt in entrance to the cella: It diverged from the Greek and Roman temples, and was more in line with ancient oriental arrangements. The cella was a longstretched building the depth of which corresponded to more than twice the width $(15.8 \mathrm{~m}$ by $39 \mathrm{~m})$. Its door was pierced in one of the long walls, and opened to the west. Inside the cella it was illuminated by sunshine coming from four large windows which were cut through two long walls. Two narrow-ends of the main hall were occupied by two monumental ensembles, each of which framed an adyton or thalamos, accessible by a porch. To designate these adyta we shall use the names, north adyton and south adyton (Figs. 7 and 8).

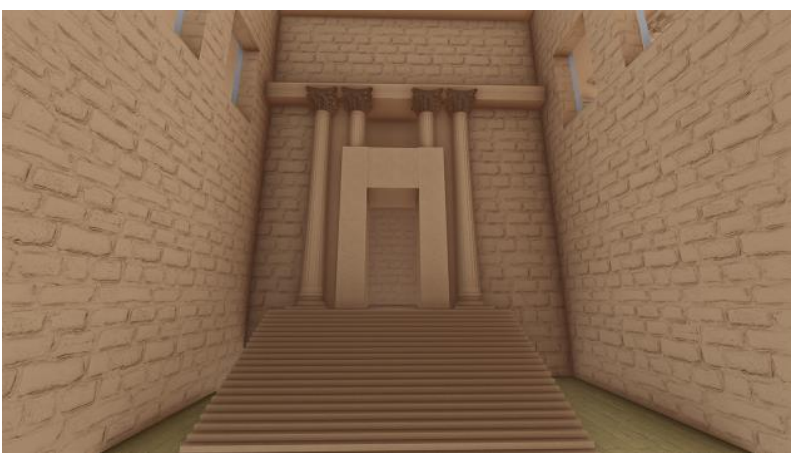

Figure 7. North adyton

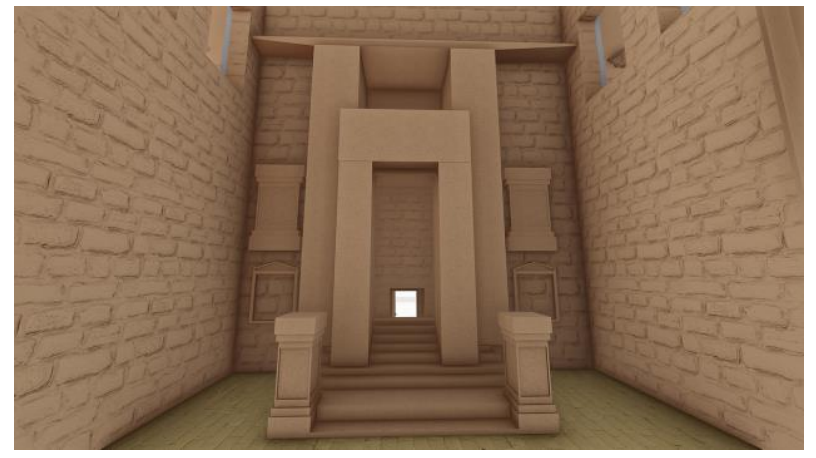

Figure 8. South adyton

The ceilings of the both adyta had elaborate decorations. The decoration which embellished the ceiling of the north adyton portrayed at its centre a series of deities. Primary deity Bel was in the centre and he was surrounded by six other deities. The seven deities were placed inside a vault so that they were also a symbolisation of the five known planets plus the moon and the sun (Fig. 9).

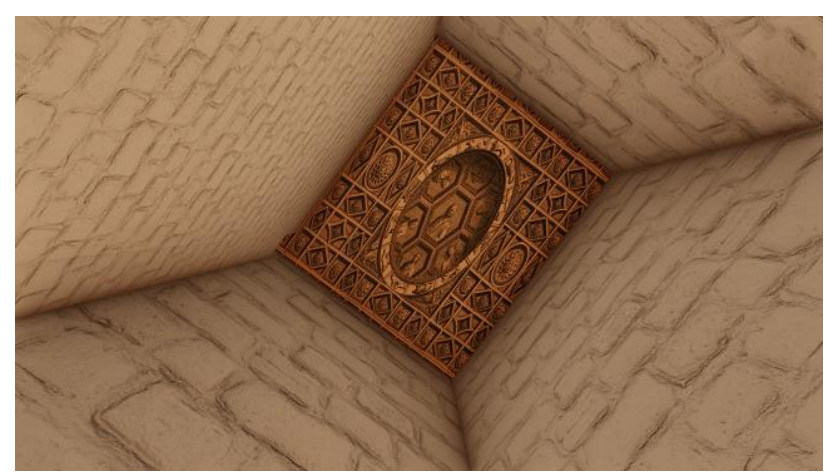

Figure 9. Celing decoration of the north adyton

The decoration of south adyton was more ornamental than religious (Fig. 10). 


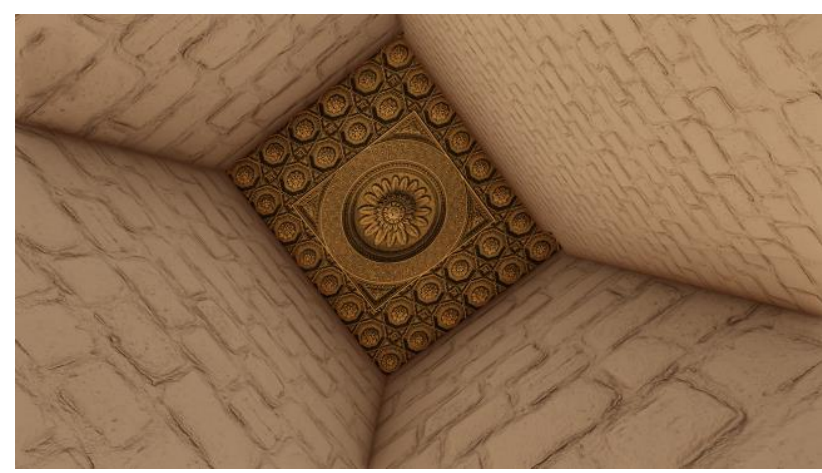

Figure 10. Celing decoration of the south adyton

Europe had learned about these decorations thanks to the drawings of Giovanni Battista Borra. After they were published in the book of R. Wood they had become the source of inspiration for many mansion ceilings.

\section{CONCLUSION}

Regrettably, since the summer of 2015 this historically significant and beautiful monument, the Great Temple of Bel which was the symbol of Palmyra's multi-cultural identity has been lost. With its loss our cultural heritage and historical memory have been vastly impoverished. The reconstruction effort put forth in this work tries to unveil the temple of Bel in our imagination, as it was in that remarkable period of wealthy Palmyra and mighty Rome (Fig. 11).

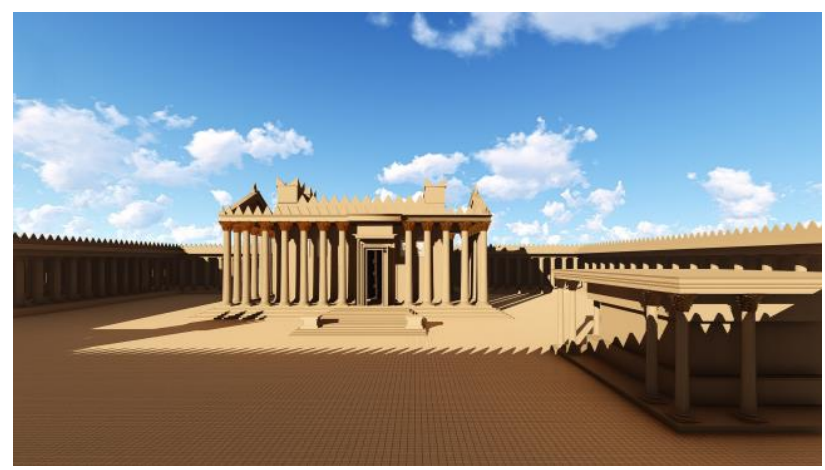

Figure 11. Great Temple of Bel as it was in Roman East

It was the accumulation of this wealth and might which could meet the enormous expenses and efforts for building this stupendous temple with its 41 bronze gilded Corinthian columns.
Destroying the Temple of Bel meant deleting part of our cultural memory. Yet, the modern technology and visualization techniques can provide some solace and healing for our memories. It is hoped with this type of reconstruction work our deleted cultural memory can be partially restored.

\section{ACKNOWLEDGEMENTS}

The author acknowledges with pride the contributions of his students Barnas Kahramaner and Uluç Yıldız in creation of the $3 \mathrm{D}$ reconstructions of this project.

\section{REFERENCES}

Denker, A., 2016. "The Virtual Palmyra: 3D Reconstruction of Lost Reality" in Archéologica 0.2, $8^{\text {th }}$ International Congress: Advanced $3 D$ Documentation, modelling and reconstruction of cultural heritage objects, monuments and sites, 5-7 September 2016, Valencia, Spain. http://arqueologica8.webs.upv.es/

Historia Augusta Aurelianus, Th Life of Aurelian Part 2, section 25, pg.245

Pliny the Elder, Natural History 5.88.1.

Schulz, B., 1932, Das grosse Hauptheiligtum des Bel, in Wiegand, T. (1932) Palmyra - Ergebnisse der Expeditionen von 1902 und 1917, Vol. I, II, Textband, Tafeln. Archeologisches Institut des Deutschen Reiches Abteilung Istanbul, Berlin: Verlag von Heinrich Keller, pp. 127-150.

Seyrig, H., Amy, R. and Will, E., 1975. Le Temple de Bel a Palmyre, Vol. I, II. Album, Texte et Planches, Institut Français d'Archéologie de Beyrouth, Bibliothèque Archéologique et Historique. T. 83. Paris: Librairie orientaliste Paul Geuthner.

Silver, M., Fangi, G., Denker, A., 2017. Reviving Palmyra in Multiple Dimensions: Images. Ruins and Cultural Memory, Whittles Publishing, U.K., ISBN 978-184995-295-5.

Wiegand, T., 1932. Palmyra Ergebnisse der Expeditionen von 1902 und 1917. Text-und Tafelbd. Available: http://digi.ub.uniheidelberg.de/diglit/wiegand1932ga

Wood, R., 1753. The ruins of Palmyra, otherwise Tedmor, in the desart. Available:

http://digi.ub.uniheidelberg.de/diglit/wood1753 